\title{
A possible crosstalk between cGMP pathway and Activin receptor-like kinase 7 (Alk7) in adipocytes
}

\author{
Aileen Balkow ${ }^{*}$, Johanna Jagow ${ }^{\dagger}$, Ana Kilic, Alexander Pfeifer \\ From 6th International Conference on cGMP: Generators, Effectors and Therapeutic Implications \\ Erfurt, Germany. 28-30 June 2013
}

\section{Background}

In last decades, obesity became a major health issue worldwide. Processes as well as molecules involved in fat mass regulation remain unresolved up to now. Brown adipose tissue (BAT) is an interesting target to fight obesity, especially since brown adipose tissue in adult humans was recently "rediscovered". In addition, the occurrence of "brown-like" adipocytes within white adipose tissue (WAT) has also sparked an interest due to potential antiobese effect. Transforming growth factor- $\beta$ (TGF- $\beta$ ) superfamily consists of structurally related but functionally diverse cytokines involved in regulation of adipogenesis. Activin receptor-like kinase-7 (Alk7), a member of the TGF- $\beta$ family, is highly expressed in adipose tissue. However, its role in adipogenesis, thermogenesis and adipocyte function is not well known.

\section{Results}

Here, we analyzed regulation of both brown and white adipocytes focusing on Alk7 pathways. Levels of Alk7 mRNA are almost negligible at the beginning of differentiation protocol. Interestingly, expression of Alk7 increases with differentiation of brown and white adipocytes and reaches highest expression levels close to the end of differentiation protocol. Chronic treatment with 8-pCPT-cGMP (200 $\mu \mathrm{M})$ increases expression of Alk7 in both brown and white adipocytes. Expression of Alk7 mRNA by cGMP is regulated via activation of PKGI, since PKGI KO adipocytes show reduced levels of Alk7. Moreover, our preliminary data suggest involvement of PKGI in Alk7 promoter activation.

\footnotetext{
* Correspondence: abalkow@uni-bonn.de

† Contributed equally

Institute of Pharmacology and Toxicology, University of Bonn, 53105 Bonn,
} Germany

C 2013 Balkow et al; licensee BioMed Central Ltd. This is an Open Access article distributed under the terms of the Creative Commons Attribution License (http://creativecommons.org/licenses/by/2.0), which permits unrestricted use, distribution, and reproduction in any medium, provided the original work is properly cited.
Presently we are investigating effects of Alk7 activation in the presence and absence of cGMP onto adipocyte differentiation and BAT function.

\section{Conclusion}

Taken together, our data show that cGMP via PKGI modulates expression of Alk7 in both white and brown adipocytes, thus pointing towards Alk7 as a new PKGI target.

Considering expression pattern of Alk7, this interaction could prove beneficial for developing new pharmacological treatments to fight obesity.

Published: 29 August 2013

doi:10.1186/2050-6511-14-S1-P4

Cite this article as: Balkow et al: A possible crosstalk between cGMP pathway and Activin receptor-like kinase 7 (Alk7) in adipocytes. BMC Pharmacology and Toxicology 2013 14(Suppl 1):P4.

Submit your next manuscript to BioMed Central and take full advantage of:

- Convenient online submission

- Thorough peer review

- No space constraints or color figure charges

- Immediate publication on acceptance

- Inclusion in PubMed, CAS, Scopus and Google Scholar

- Research which is freely available for redistribution

Submit your manuscript at www.biomedcentral.com/submit 